\title{
STUDI PENGGUNAAN PASIR DAN POZZOLAN ALAM TERHADAP DAYA TAHAN API PAPERCRETE
}

\author{
Surya Bermansyah $^{1)}$, Yulia Hayati ${ }^{2)}$, Lia Mairiza $^{3)}$, Rita Ofiani ${ }^{4)}$ \\ Jurusan Teknik Sipil, Fakultas Teknik, Universitas Syiah Kuala. \\ (surya_cesp@unsyiah.ac.id; yulia_71@yahoo.com; \\ liamairiza@yahoo.com;rita_ofiani@yahoo.com;)
}

\begin{abstract}
Abstrak
Penelitian ini bertujuan untuk mengetahui pengaruh komposisi pozzolan alam terhadap daya tahan api beton kertas (papercrete). Penelitian terdahulu terhadap campuran papercrete komposisi volume semen dan pasir $1: 3,5$ menunjukkan bahwa penggunaan variasi bubur kertas yang optimal pada porsi pasir adalah $62 \%$ sehingga komposisi volume semen-pasir-bubur kertas menjadi $1: 1,3: 2,2$; dengan FAS 0,35. Komposisi volume pozzolan alam yang digunakan adalah dari 1 bagian pasir, yaitu 50\%, 60\%, 70\%, 80\%, 90\%, dan $100 \%$. Benda uji yang digunakan adalah pelat ukuran 100 $\mathrm{cm} \times 100 \mathrm{~cm} \times 3,5 \mathrm{~cm}$. Hasil pengujian daya tahan api menunjukkan beton kertas (papercrete) dengan komposisi pozzolan alam 50\%, 60\% dan $70 \%$ tergolong dalam kategori bahan menahan api (fire retardant). Kategori ini tergolong kategori menengah untuk bahan bangunan yang baik berdasarkan ketahanannya tehadap bahaya kebakaran. Untuk beton kertas dengan komposisi pozzolan alam 80\%, 90\% dan $100 \%$ tergolong dalam kategori bahan sukar terbakar (semi noncombustible). Kategori ini tergolong baik untuk bahan bangunan berdasarkan ketahanannya tehadap bahaya kebakaran.
\end{abstract}

Kata kunci: beton kertas, pozzolan alam, daya tahan api.

\section{Pendahuluan}

Beton ringan telah digunakan untuk berbagai jenis konstruksi teknik sipil sejak puluhan tahun lalu terutama di negara Eropa, Amerika Utara, Jepang, dan Australia. Beton ini terus dikembangkan karena kelebihannya dibanding beton normal sehingga lebih mudah diangkut dan dipasang pada saat pengerjaan. Konstribusinya terhadap beban mati juga lebih ringan sehingga baik digunakan pada daerah-daerah rawan gempa. Salah satu cara menciptakan beton ringan adalah mengurangi berat yang ditimbulkan oleh agregat dengan mensubtitusi proporsi agregat dalam campuran beton dengan material alternatif yang mendukung dari segi karakteristik dan ekonomi. Kertas adalah material ringan berbahan dasar serat yang mengandung senyawa oksida yang merupakan bahan dasar dalam pembuatan klinker semen. Selaras dengan UU No.32 tahun 2009 dan Peraturan Menteri Negara Lingkungan Hidup No.02 Tahun 2008 tentang pengelolaan lingkungan hidup dengan mendayagunakan kembali bahan limbah,

Studi Penggunaan Pasir dan Pozzolan Alam Terhadap Daya Tahan Api Papercrete - 
maka pemanfaatan kertas limbah sebagai bahan campuran beton merupakan alternatif yang dapat diaplikasikan.

Penelitian Bermansyah dkk $\left(2011^{\mathrm{a}}\right)$ terhadap beton kertas menggunakan kerikil dan pasir dengan substitusi bubur kertas sebesar 50\% dari seluruh agregat diperoleh berat jenis beton sebesar $1,666 \mathrm{gr} / \mathrm{cm}^{3}$ sehingga dapat dikelompokkan sebagai beton ringan. Namun dibandingkan dengan kuat tekan beton normal, beton kertas memiliki kekuatan yang masih rendah. Penelitian Bermansyah dkk $\left(2011^{\mathrm{b} / \mathrm{c}}\right)$ terhadap beton kertas menggunakan kerikil dan pasir dengan substitusi bubur kertas serta penambahan pozzolan alam menunjukkan bahwa kuat tekan, kuat tarik belah, dan kuat tarik lentur dari papercrete dengan $70 \%$ pozzolan alam memberikan kapasitas yang lebih optimal dari komposisi lainnya.

Sama pada penelitian sebelumnya, maka pada penelitian ini digunakan kertas jenis HVS yang didapat dari limbah aktifitas kantor dan rumah tangga. Kertas awalnya dihancurkan menjadi bubur kertas dan kemudian digunakan sebagai substitusi agregat pada beton. Penambahan pozzolan alam ini diharapkan dapat menjadi pengisi (filler) dalam beton serta kandungan silika dan aluminanya diharapkan dapat meningkatkan rekatan antar partikel beton kertas menghasilkan beton dengan daya tahan api. Penelitian ini dilakukan di Laboratorium Konstruksi dan Bahan Bangunan (LKBB) Fakultas Teknik Universitas Syiah Kuala - Banda Aceh.

\section{Tinjauan Kepustakaan}

\subsection{Beton Ringan dan Beton Kertas (Lightweight Concrete and Papercrete)}

Beton dikualifikasikan menjadi dua golongan yaitu beton normal dan beton ringan. Beton normal tergolong beton yang memiliki densitas sekitar 2200 - 2400 $\mathrm{kg} / \mathrm{m}^{3}$. Beton ringan adalah suatu beton yang memiliki densitas kurang dari 1800 $\mathrm{kg} / \mathrm{m}^{3}$ (Maidayani, 2009). Nasution (2009) menjelaskan, penggunaan beton ringan sebagai bahan konstruksi bangunan sipil tidak saja akan menghasilkan berat total bangunan menjadi lebih ringan, kandungan udara dalam beton dengan ukuran diameter yang sangat kecil, kira-kira 0,1-1,0 mm dan tersebar merata (homogen) menjadikan beberapa sifat beton lebih baik, misalnya sebagai penghambat panas (heat insulation) dan lebih kedap suara (sound insulation) dibandingkan dengan bahan dinding yang umum dipakai seperti batu bata dan batako.

Penelitian Pribadi (2009) menjelaskan, beton kertas adalah suatu material bangunan yang dibuat dari campuran kertas yang didaur ulang, semen portland, pasir dan air. Kertas yang digunakan adalah kertas bekas yang diolah menjadi bubur kertas dengan tujuan mempermudah proses pengadukan campuran.

Bubur kertas memiliki beberapa senyawa oksida seperti Silikon Dioksida $\left(\mathrm{SiO}_{2}\right)$, Alumunium Oksida $\left(\mathrm{Al}_{2} \mathrm{O}_{3}\right)$, Magnesium Oksida $(\mathrm{MgO})$, Kalsium Oksida $(\mathrm{CaO})$, Ferri Oksida $\left(\mathrm{Fe}_{2} \mathrm{O}_{3}\right)$, dimana oksida-oksida tersebut merupakan bahan dasar untuk membuat produk klinker semen. Senyawa yang paling dominan di dalam limbah adalah Kalsium Oksida $(\mathrm{CaO})$ sebesar 56,38\%, air $\left(\mathrm{H}_{2} \mathrm{O}\right) 16,11 \%$, Sulfur Trioksida $\left(\mathrm{SO}_{3}\right)$ 11,26\% serta beberapa unsur lain (Ray dan Juis, 2009). 
Hasil penelitian, Widjaja (2008) menyimpulkan semakin banyak bubur kertas yang dicampurkan pada papan beton maka semakin kecil nilai densitasnya. Penambahan bubur kertas yang disertai pengurangan pasir dalam papan beton menunjukkan nilai berat panel yang semakin kecil. Perubahan tersebut dipengaruhi oleh faktor penyusun, salah satunya adalah berat jenis. Berat jenis pasir dan kerikil sekitar 2,1-2,2 $\mathrm{gr} / \mathrm{cm}^{3}$ lebih besar daripada berat jenis bubur kertas dalam keadaan kering permukaan yaitu $1,24 \mathrm{gr} / \mathrm{cm}^{3}$, sedangkan dalam keadaan kering oven adalah 0,47 gram $/ \mathrm{cm}^{3}$ dengan nilai modulus kehalusan butir sebesar 3,98 dan absorbsi kertas 78\%. Hardiani (2009) juga menjelaskan bubur kertas memiliki berat volume sebesar $0,67 \mathrm{~kg} / \mathrm{l}$. Untuk mendapatkan beton kertas bermutu baik (kuat tekan tinggi) maka harus dipergunakan Faktor Air Semen (FAS) rendah, namun jika FAS-nya terlalu kecil pengerjaan beton akan menjadi sangat sulit, sehingga pemadatannya tidak bisa maksimal dan akan mengakibatkan beton menjadi keropos (Gunarto, 2008 : 790).

Penelitian Bermansyah dkk $\left(2011^{\mathrm{a}}\right)$ terhadap 3 variasi perbandingan volume proporsi bubur kertas dan agregat (pasir dan batu pecah), yaitu campuran PA50 (50\% Kertas : 50\% Agregat), PA40 (40\% Kertas : 60\% Agregat) dan PA30 (30\% Kertas : 70\% Agregat) menunjukkan bahwa hasil analisis varian substitusi bubur kertas di dalam beton berpengaruh nyata terhadap kuat tekan beton, dimana hasil pengujian diperoleh kuat tekan untuk PA50 adalah $89,50 \mathrm{~kg} / \mathrm{cm}^{2}$, untuk PA40 adalah $140,10 \mathrm{~kg} / \mathrm{cm}^{2}$ dan untuk PA30 adalah $157,10 \mathrm{~kg} / \mathrm{cm}^{2}$. Workabilitas adukan beton terlihat bahwa nilai slump pada beton kertas (papercrete) lebih rendah dibandingkan beton tanpa kertas, hal ini menunjukkan bahwa dengan semakin banyaknya proporsi kertas didalam campuran membuat campuran semakin kental, kaku dan sulit untuk dikerjakan. Pengukuran modulus elastisitas beton kertas menunjukkan bahwa semakin besar proporsi bubur kertas didalam campuran maka akan semakin besar pula nilai modulus elastisitas. Semakin banyak kandungan kertas didalam beton membuat beton menjadi semakin daktail.

\subsection{Pozzolan Alam}

Pozzolan merupakan bahan yang mengandung senyawa silika alumina, yang tidak mempunyai sifat mengikat seperti semen akan tetapi dalam bentuknya yang halus dan dengan adanya air, maka senyawa-senyawa tersebut akan bereaksi dengan kalsium hidroksida pada suhu normal membentuk senyawa kalsium silikat hidrat dan kalsium hidrat yang bersifat hidraulis (Sanjaya, 2008 : 110).

Menurut ASTM C.593-82, bila dilihat dari proses pembentukannya, bahan pozzolan dapat dibedakan menjadi dua jenis, yaitu pozzolan buatan dan pozzolan alam. Pozzolan buatan berasal dari tungku maupun hasil pemanfaatan limbah yang diolah menjadi abu yang mengandung silika melalui proses pembakaran, seperti abu terbang (fly ash), abu sekam (rice husk ash) dam mikro silika (silica fume). Sedangkan pozzolan alam adalah bahan alam yang merupakan timbunantimbunan atau bahan sedimentasi dari abu atau lava gunung berapi yang mengandung silika.

Saputra (2010) menyatakan bahwa pozzolan alam yang diambil dari Ujong Batee-Aceh Besar telah memenuhi syarat setelah melalui pemeriksaan komposisi 
kimia, berat jenis, dan modulus kehalusan dimana sifat fisis yang dimiliki memenuhi standar ASTM C.618-78 dengan kandungan $\mathrm{SiO}_{2}=42,96 \%, \mathrm{Fe}_{2} \mathrm{O}_{3}=$ $1,92 \%, \mathrm{CaO}=0,42 \%, \mathrm{MgO}=0,28 \%, \mathrm{Na}_{2} \mathrm{O}=0,13 \%, \mathrm{~K}_{2} \mathrm{O}=0,36 \%, \mathrm{TiO}_{2}=$ $0,12 \%$, berat jenis sebesar 1,21 dan modulus kehalusan 2,259.

Penelitian Bermansyah dkk $\left(2011^{\mathrm{b}}\right)$ menunjukkan bahwa hasil analisis data pengujian kuat tekan beton kertas menggunakan pozzolan alam menunjukkan adanya pengaruh pozzolan alam terhadap kuat tekan beton kertas. Peningkatan penggunaan pozzolan alam pada setiap variasi menyebabkan penurunan berat volume, berat jenis benda uji pada umur 28 hari. Hal ini dikarenakan berat jenis pozzolan lebih kecil dari berat jenis pasir. Dari enam variasi campuran peningkatan kuat tekan yang paling maksimum terjadi pada penggunaan pozzolan alam terhadap pasir sebesar $70 \%$ yaitu $106,750 \mathrm{~kg} / \mathrm{cm}^{2}$ dengan selisih naik $49,791 \%$ dari kuat tekan beton kertas pembanding yaitu beton kertas tanpa penggunaan pozzolan alam sebesar $71,490 \mathrm{~kg} / \mathrm{cm}^{2}$. Berdasarkan kekuatannya beton kertas menggunakan pozzolan alam dengan proporsi penggunaan pozzolan alam sebesar $70 \%$ dapat dkategorikan sebagai beton ringan dengan kekuatan menengah (moderate strength concretes) dan dapat direkomendasikan pada bangunan sederhana (non engineering building).

Hal yang sama disampaikan pada penelitian Bermansyah dkk (2011 $)$ dimana hasil analisis data pengujian kuat tarik belah dan kuat tarik lentur beton kertas menggunakan pozzolan alam menunjukkan adanya pengaruh pozzolan alam terhadap kuat tarik belah dan kuat tarik lentur beton kertas jika dibandingkan terhadap beton kertas tanpa pozzolan alam. Peningkatan kuat tarik belah yang paling maksimum terjadi pada penggunaan pozzolan alam sebesar $60 \%$ terhadap pasir yaitu $17,715 \mathrm{~kg} / \mathrm{cm}^{2}$ (naik $19,955 \%$ ) jika dibandingkan dengan kuat tarik beton kertas normal sebesar $14,768 \mathrm{~kg} / \mathrm{cm}^{2}$. Sedangkan untuk pengujian kuat tarik lentur peningkatan maksimum terjadi pada penggunaan pozzolan alam sebesar $50 \%$ terhadap pasir yaitu $53,161 \mathrm{~kg} / \mathrm{cm}^{2}$ (naik 91,929\%) jika dibandingkan dengan kuat lentur beton kertas normal sebesar $27,698 \mathrm{~kg} / \mathrm{cm}^{2}$. Penggunaan pozzolan alam sebanyak $50 \%-60 \%$ terhadap pasir menghasilkan berat jenis (BJ) beton kertas sebesar 1,589-1,559 dan memberikan kuat tarik belah dan kuat tarik lentur yang lebih baik daripada beton kertas tanpa pozzolan alam.

\subsection{Daya tahan api}

Menurut Ahmad dkk (2009) kebakaran pada hakekatnya merupakan reaksi kimia dari combustible material dengan oksigen yang dikenal dengan reaksi pembakaran yang menghasilkan panas. Panas hasil pembakaran ini diteruskan ke massa beton dengan dua macam mekanisme yakni pertama secara radiasi yaitu pancaran panas diterima oleh permukaan beton sehingga permukaan beton menjadi panas. Pancaran panas akan sangat potensial, jika suhu sumber panas relatif tinggi. Kedua secara konveksi yaitu udara panas yang bertiup/ bersinggungan dengan permukaan beton sehingga beton menjadi panas. Bila tiupan angin semakin kencang, maka panas yang dipindahkan dengan cara konveksi semakin banyak. 
Kebakaran adalah penyebab utama hancurnya struktur bangunan dan hilangnya umur bangunan. Menurut Nugraha dan Antoni (2007), perubahan temperatur yang cukup tinggi seperti yang terjadi pada peristiwa kebakaran, akan membawa dampak pada struktur beton. Dalam kebakaran temperatur dapat naik cukup cepat dan menimbulkan tegangan dalam yang mampu menyingkirkan lapisan permukaan beton. Hal ini akan mempengaruhi kualitas/kekuatan struktur beton tersebut.

Sifat-sifat beton pada suhu tinggi dipengaruhi oleh jenis agregat penyusunnya. Pada beton terdapat tiga jenis agregat yaitu karbonat, silika, dan agregat berbobot ringan. Agregat yang mengandung banyak silika tidak mengalami perubahan kimia pada suhu yang biasa dijumpai dalam kebakaran. Beton yang beragregat silika tidak menunjukkan perubahan volume atau sifat fisika lainnya secara tiba-tiba. Agregat berbobot ringan seperti pozzolan alam atau abu sekam padi mengalami pemanasan sampai sekitar $1040^{\circ} \mathrm{C}$ sampai $1100^{\circ} \mathrm{C}$ selama proses pembuatan sehingga memiliki ketahanan api yang baik (Ray, 2009).

Menurut Standar Nasional Indonesia (SNI) 03-1739-1989, ada 5 klasifikasi mutu bahan bangunan yang dapat terbakar pada bangunan rumah dan gedung yaitu tidak terbakar (noncombustible), sukar terbakar (semi non-combustible), menahan api (fire retardant), agak menahan api (semi fire retardant), dan mudah terbakar (easily combustible).

Tabel 1 Klasifikasi Bahan Bangunan

\begin{tabular}{|c|c|c|c|c|c|}
\hline & $\begin{array}{c}\text { Tidak } \\
\text { Terbakar }\end{array}$ & $\begin{array}{c}\text { Sukar } \\
\text { Terbakar }\end{array}$ & $\begin{array}{c}\text { Menahan } \\
\text { Api }\end{array}$ & $\begin{array}{c}\text { Agak Menahan } \\
\text { Api }\end{array}$ & $\begin{array}{c}\text { Mudah } \\
\text { Terbakar }\end{array}$ \\
\hline $\begin{array}{c}\text { Luas kurva } \\
\text { suhu-waktu (menit }{ }^{\circ} \mathrm{C} \text { ) }\end{array}$ & 0 & $\begin{array}{c}\text { Tidak lebih } \\
\text { dari } 100\end{array}$ & $100-200$ & $201-350$ & Lebih dari 350 \\
\hline $\begin{array}{c}\text { Perubahan } \\
\text { Bentuk }\end{array}$ & \multicolumn{5}{|c}{$\begin{array}{c}\text { Tidak terjadi lelehan melebihi tebalnya } \\
\text { Tidak terjadi deformasi yang membahayakan }\end{array}$} \\
\hline Lain-lain & \multicolumn{5}{|c|}{ Tidak mengeluarkan gas beracun } \\
\hline
\end{tabular}

\section{Sumber: SNI 03-1739-1989}

Pengklasifikasian diatas diperoleh berdasarkan luas kurva $\left(\right.$ menit $\left.^{\circ} \mathrm{C}\right)$ yang melewati batas kurva suhu standar yang diperoleh dari grafik pengujian pembakaran benda uji.

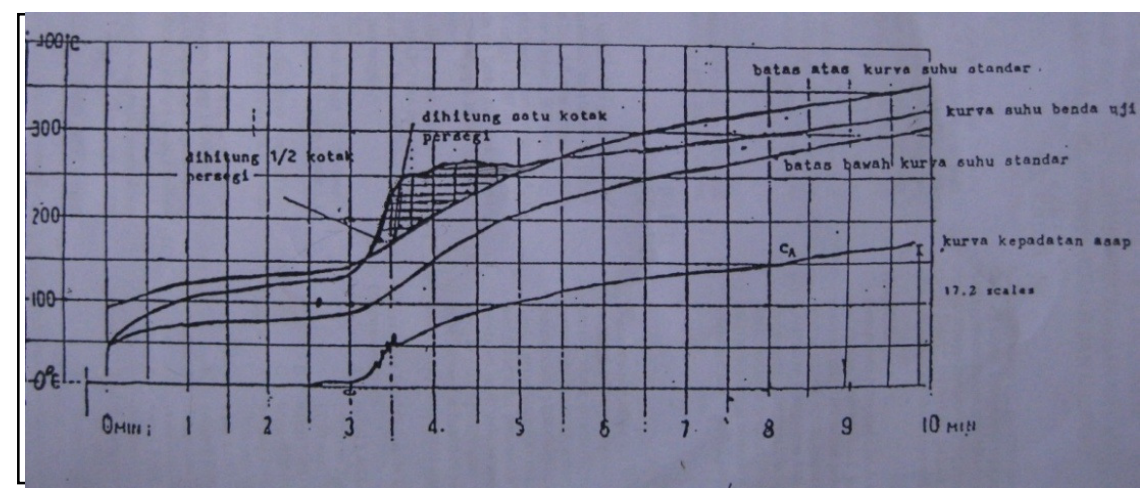

Gambar 1 Grafik Hubungan Waktu dan Suhu Standar

Sumber: SNI 03-1739-1989

Studi Penggunaan Pasir dan Pozzolan Alam Terhadap Daya Tahan Api Papercrete - 


\section{Metode Penelitian}

Pada penelitian ini komposisi beton kertas terdiri dari semen, air, bubur kertas, pasir, dan pozzolan alam. Campuran komposisi volume awal semen dan pasir adalah 1 : 3,5 dengan faktor air semen 0,35. Variasi penggunaan bubur kertas pada porsi pasir adalah $60 \%$ sehingga komposisi volume semen-pasirbubur adalah $1: 1,3: 2,2$. Komposisi volume pozzolan selanjutnya adalah variasi dari 1 bahagian pasir tersebut, yaitu 50\%, 60\%, 70\%, 80\%, 90\%, dan $100 \%$. Benda uji yang digunakan adalah pelat ukuran $22 \mathrm{~cm}$ x $22 \mathrm{~cm} \times 3,5 \mathrm{~cm}$.

Material yang digunakan adalah semen PC-I, bubur kertas, agregat halus, pozzolan alam, dan air. Agregat halus dan pozzolan alam terdiri dari butiran lolos saringan 4,76 mm. Bubur kertas berasal dari kertas HVS bekas yang dihaluskan menggunakan grinder dan lolos saringan 4,76 mm pada keadaan kering.

Pencampuran material menggunakan molen, secara bertahap dimasukkan bubuk kertas kering, pasir, pozzolan alam, dan semen diaduk terlebih dahulu agar bahan-bahan teraduk merata, kemudian dimasukkan air sesuai kebutuhan perencananaan (air fas dan bubur) dan diaduk 3-5 menit.

Setelah proses pengadukan selesai, dilakukan pengujian terhadap fresh concrete (beton segar) yang meliputi pengujian slump dan berat volume. Untuk pengujian slump menggunakan kerucut Abram's sesuai dengan ketentuan ASTM C.143-78 (Anonim, 2004). Pengukuran berat volume mortar dilakukan dengan menimbang mortar yang dimasukkan dalam wadah dengan volume 1 liter.

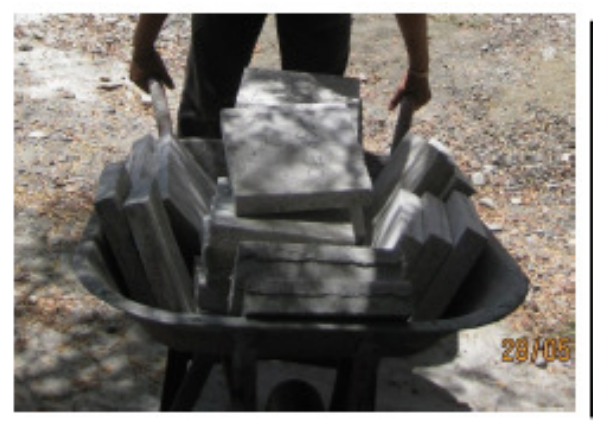

a. benda uji $22 \times 22 \times 3,5 \mathrm{~cm}$

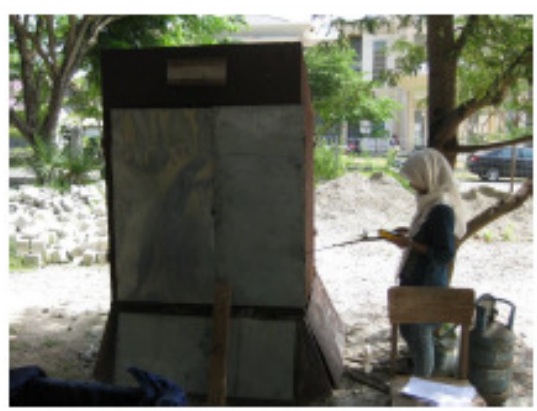

c. tungku pembakaran

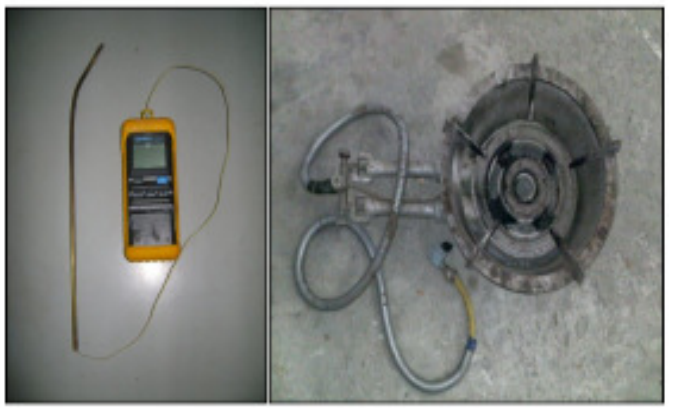

b. thermocouple dan kompos gas

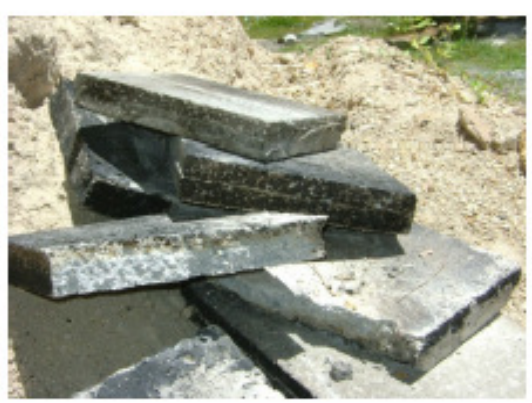

b. benda uji setelah dibakar

Bahan yang telah dicampur dimasukan ke dalam cetakan sesuai dengan cetakan benda uji yang dibuat. Pembuatan benda uji dilakukan dengan mengisi mortar ke dalam cetakan. Pemadatan dilakukan dengan menggunakan raskam karena ketebalannya yang kecil sehingga sulit untuk pemadatan jika hanya 
menggunakan tongkat pemadatan atau kayu. Pembukaan cetakan dilakukan setelah benda uji berumur 24 jam. Benda uji dirawat pada suhu ruangan selama 28 hari terhitung saat benda uji selesai dicetak. Pengujian daya tahan api mengacu pada Standar Nasional Indonesia (SNI) 03-1739-1989.

\section{Hasil dan Pembahasan}

\subsection{Slump dan Berat Volume}

Pengaruh persentase penggunaan pozzolan alam terhadap nilai slump dan berat volume beton kertas diperlihatkan pada Gambar 2. Dari gambar terlihat bahwa, semakin banyak komposisi pozzolan alam yang digunakan semakin kecil nilai slump pada mortar (beton segar). Hal ini menunjukkan bahwa penambahan pozzolan alam menurunkan workabilitas beton kertas. Berdasarkan hasil pengukuran berat volume beton segar menunjukkan bahwa penggunaan pozzolan alam dapat menurunkan berat volume beton kertas. Hal ini dikarenakan pozzolan alam memiliki berat jenis yang lebih ringan dibanding pasir.

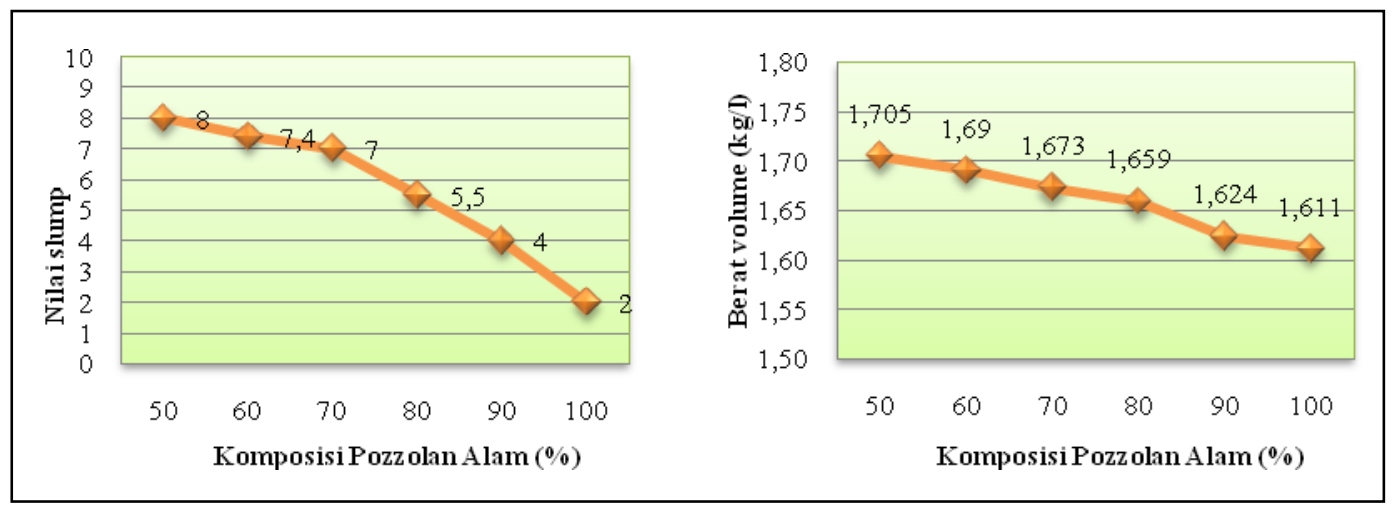

\section{Gambar 2 Grafik Hubungan Komposisi Pozzolan Alam Terhadap Nilai} Slump dan Berat Volume Beton Segar

\subsection{Daya Tahan Api Papercrete}

Hasil pengujian menunjukkan luas kurva untuk masing-masing benda uji mengalami peningkatan untuk setiap penambahan komposisi pozzolan alam.

Tabel 2 Luas Kurva Rata-rata dan Kategori Bahan

\begin{tabular}{|l|c|c|c|c|c|c|}
\hline \multirow{2}{*}{$\begin{array}{l}\text { Luas Kurva Rata-rata } \\
\text { (menit }{ }^{\circ} \text { C) }\end{array}$} & PP 50 & PP 60 & PP 70 & PP 80 & PP 90 & PP 100 \\
\hline $\begin{array}{l}\text { Kategori Bahan } \\
\begin{array}{l}\text { Menurut } \\
\text { SNI 03-1739-1989 }\end{array}\end{array}$ & $\begin{array}{c}\text { Menahan } \\
\text { api }\end{array}$ & $\begin{array}{c}\text { Menahan } \\
\text { api }\end{array}$ & $\begin{array}{c}\text { Menahan } \\
\text { api }\end{array}$ & $\begin{array}{c}\text { Sukar } \\
\text { terbakar }\end{array}$ & $\begin{array}{c}\text { Sukar } \\
\text { terbakar }\end{array}$ & $\begin{array}{c}\text { Sukar } \\
\text { terbakar }\end{array}$ \\
\hline
\end{tabular}

Hasil pengujian daya tahan api menunjukkan beton kertas (papercrete) dengan komposisi pozzolan alam 50\%, 60\% dan 70\% tergolong dalam kategori bahan menahan api (fire retardant). Kategori ini tergolong kategori menengah untuk bahan bangunan yang baik berdasarkan ketahanannya tehadap bahaya kebakaran. Untuk beton kertas dengan komposisi pozzolan alam 80\%, 90\% dan $100 \%$ tergolong dalam kategori bahan sukar terbakar (semi non-combustible). 
Kategori ini tergolong baik untuk bahan bangunan berdasarkan ketahanannya tehadap bahaya kebakaran. Dalam kebakaran temperatur dapat naik cukup cepat dan menimbulkan tegangan dalam yang mampu menyingkirkan lapisan permukaan beton. Hal ini akan mempengaruhi kualitas/kekuatan struktur beton tersebut.

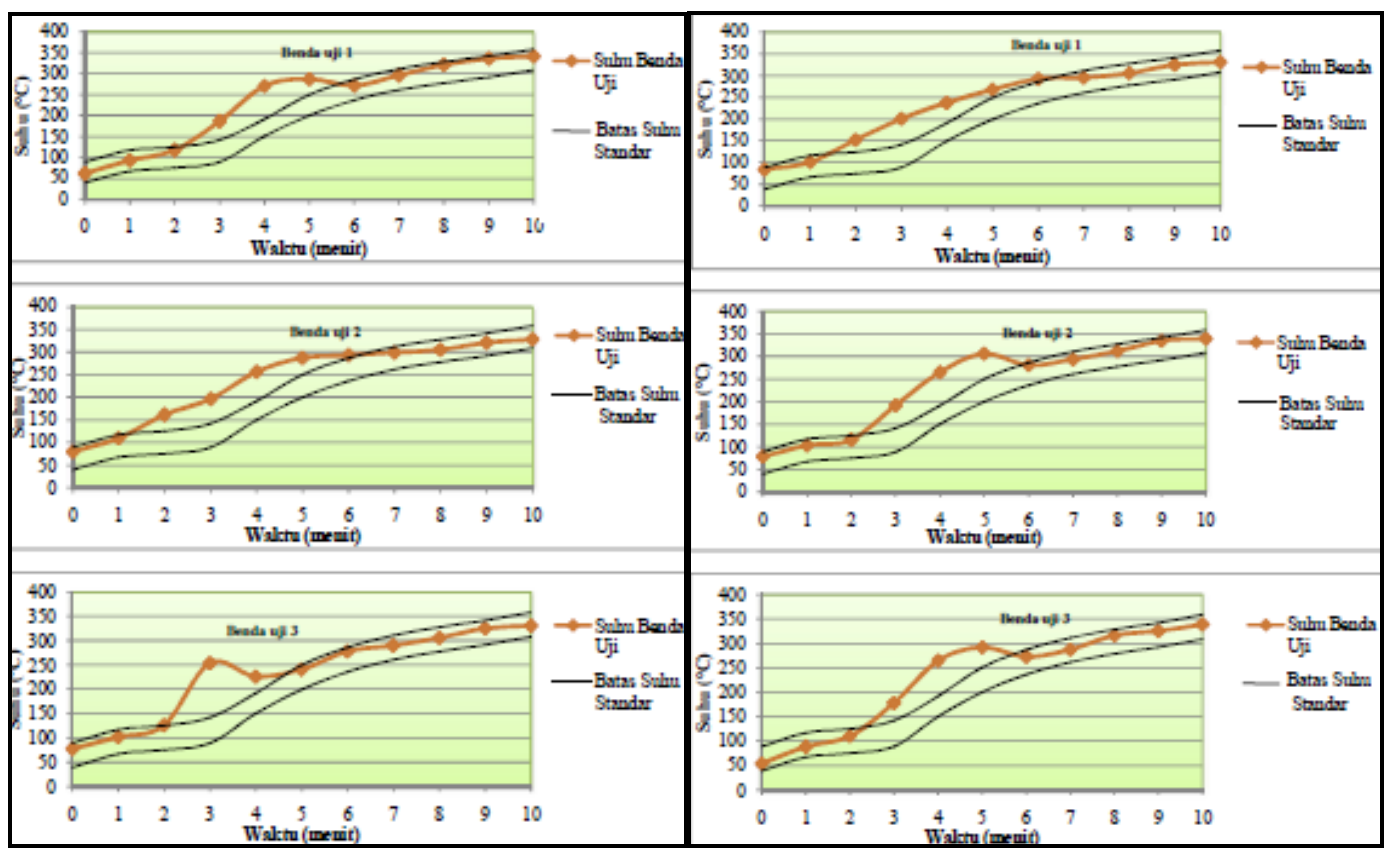

Gambar 3 Grafik Hubungan antara Waktu dan Suhu pada PP50 dan PP60

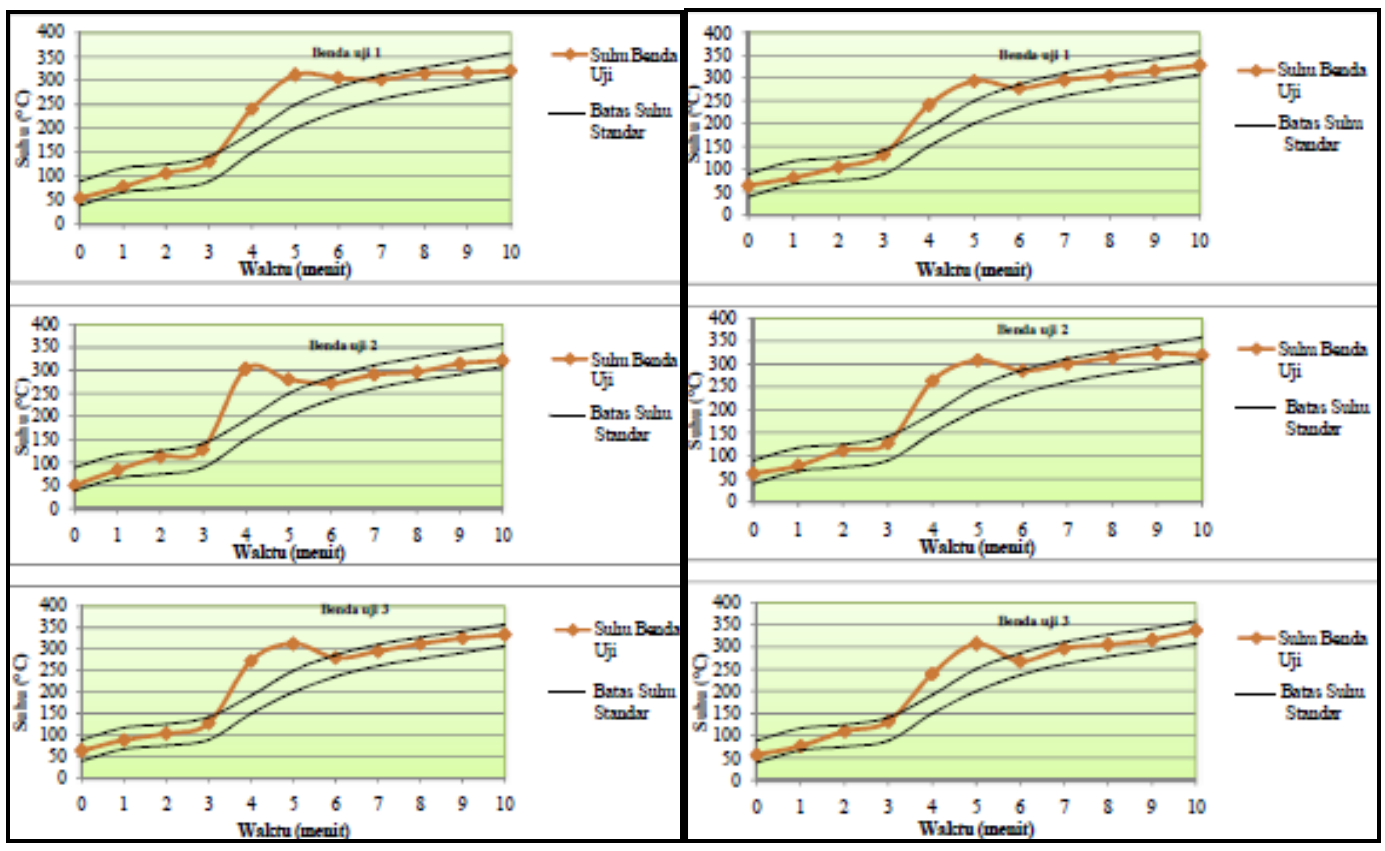

Gambar 4 Grafik Hubungan antara Waktu dan Suhu pada PP70 dan PP80

Hasil pengujian menunjukkan adanya penurunan luas kurva pada setiap penambahan komposisi pozzolan alam. Ini berarti semakin besar jumlah persentase komposisi pozzolan alam dalam beton kertas maka daya tahan beton terhadap api akan semakin meningkat dan baik. Hal ini sesuai dengan pendapat 
Ray (2009) bahwa agregat berbobot ringan seperti pozzolan alam yang merupakan bahan sedimentasi dari abu atau lava gunung berapi adalah salah satu material yang sangat baik menahan api. Karena pada proses pembentukannya,material pozzolan telah terbakar pada $1000-1100^{\circ} \mathrm{C}$. Dalam peristiwa kebakaran, suhu dapat naik dengan sangat cepat dan akan membakar material-material yang gampang terbakar. Keberadaan pozzolan alam mampu melindungi kondisi material kertas yangmudah terbakar.

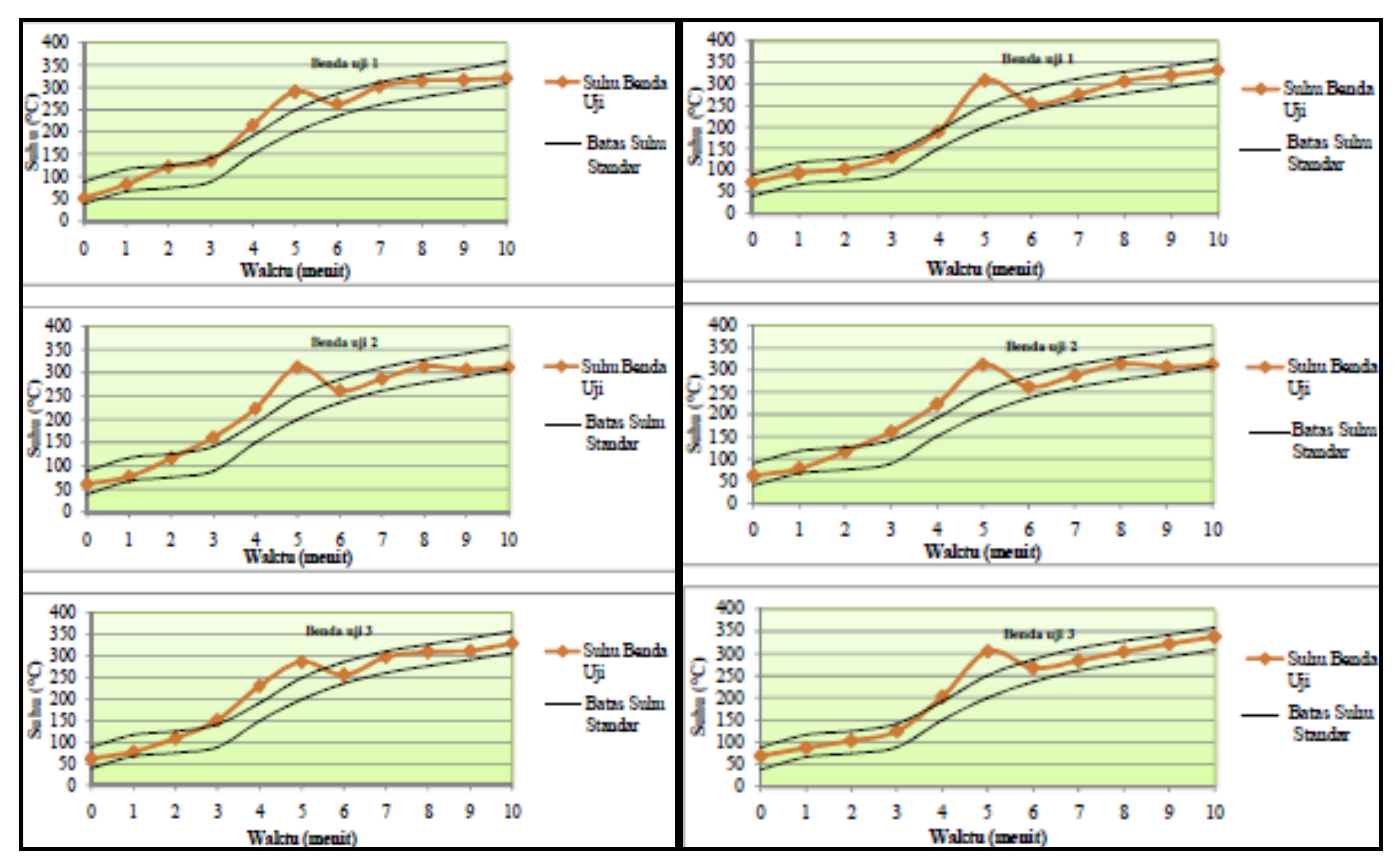

\section{Gambar 5 Grafik Hubungan antara Waktu dan Suhu pada PP70 dan PP80}

Kertas merupakan bahan yang mudah terbakar. Penggunaan kertas dalam campuran beton mengakibatkan ketahanan beton terhadap api menurun. Penambahan pozzolan alam yang merupakan bahan sedimentasi dari larva gunung berapi terbukti dapat memperbaiki ketahanan beton terhadap api.

\section{Kesimpulan}

Kesimpulan yang dapat diambil dari hasil penelitian ini adalah semakin besar komposisi pozzolan alam, daya tahan papercrete terhadap api semakin baik. Semakin besar komposisi pozzolan alam, daya tahan papercrete terhadap api semakin baik. Papercrete dengan komposisi pozzolan alam 50\%, 60\% dan 70\% tergolong dalam kategori bahan menahan api (fire retardant). Papercrete dengan komposisi pozzolan alam $80 \%, 90 \%$ dan $100 \%$ tergolong dalam kategori bahan sukar terbakar (semi noncombustible).

\section{Daftar Kepustakaan}

1. Anonim, 1989, SNI: 03-1739-1989, Standar Nasional Indonesia, Badan Standarisasi Nasional, Jakarta.

2. Anonim, 2004, Annual Book of ASTM Standard 2004, Section 4, Volume 04.02, Concrete and Aggregates, International Standards-Worldwide 
3. Ahmad, I. A., dkk, 2009, Analisis Pengaruh Temperatur Terhadap Kuat Tekan Beton, Jurnal Teknik Sipil, Vol. 16, No. 2, halaman 63 - 70.

4. Bermansyah, S., Huzaim, dan Irvan, 2011 ${ }^{\mathrm{A}}$, Pengaruh Substitusi Bubur Kertas sebagai Campuran Agregat terhadap Kuat Tekan Beton, Prosiding Seminar API, 26 Mei 2011, Banda Aceh;

5. Bermansyah, S., Huzaim, dan Rinaldi, 2011 ${ }^{\mathrm{B}}$, Pengaruh Penggunaan Pozzolan Alam Terhadap Kuat Tekan Papercrete, Proceeding Seminar Reguler Teknik Sipil, 23 Desember 2011, BandaAceh;

6. Bermansyah, S., Yulia Hayati, dan Maulida Oktavina, $2011^{\mathrm{C}}$, Analisis Kuat Tarik Belah dan Kuat Tarik Lentur Papercrete Menggunakan Pozzolan Alam, Teras Jurnal, Vol 1 nomor 2 Juni 2011, Lhokseumawe;

7. Gunarto, A., dkk, 2008, Pemanfaatan Limbah Kertas Koran Untuk Pembuatan Panel Papercrete, Forum Teknik Sipil, No. XVIII, halaman 788797.

8. Hardiani, 2009, Pemanfaatan Limbah Sludge Industri Kertas Sigaret Untuk Bahan Baku Bata Beton, Jurnal BS, Vol. 44, No.2, halaman 86 - 98.

9. Maidayani, 2009, Pengaruh Aditif Lateks Dan Komposisi Terhadap Karakteristik Beton Dengan Menggunakan Limbah Padat (Sludge) Industri Kertas, Universitas Sumatera Utara, Medan.

10. Nasution, S., 2009, Efek Komposisi Dan Aging Terhadap Sifat Mekanik Dan Fisis Pada Pembuatan Aerated Concrete (Beton Berpori), Universitas Sumatera Utara, Medan.

11. Nugraha, P., dan Antoni, 2007, Teknologi Beton (Dari Material, Pembuatan, ke Beton Kinerja Tinggi), Penerbit Andi, Yogyakarta.

12. Pribadi, A., 2009, Tinjauan Absorbsi Dan Permeabilitas Beton Kertas Pada Variasi Campuran, Universitas Sebelas Maret, Solo.

13. Ray, N., 2009, Pengaruh W/C Ratio Pada Perubahan Perilaku Beton Mutu Normal Pada Temperatur Tinggi Pasca Kebakaran, Jurnal Teknik Sipil ITATS, halaman $1-14$.

14. Ray, N., dan Juis W. U., 2009, Alternatif Penggunaan Limbah Pabrik Kertas Sebagai Pengganti Semen (Cementitous) Dalam Pembuatan Beton, Universitas Muhammadiyah, Surakarta.

15. Sanjaya, P. A., 2008, Pengaruh Penambahan Pozzolan Alam Batu Apung Terhadap Karakteristik Genteng, Jurnal Ilmiah Teknik Sipil, Vol.12 No.2, halaman $105-116$.

16. Saputra, J., 2010, Pengaruh Penggantian Semen Dengan Abu Pozzolan Alami Terhadap Sifat Mekanis Beton Busa (Foamed Concrete), Universitas Syiah Kuala,

17. Widjaja, A., 2008, Limbah Bubur Kertas Untuk Papan Beton, Fakultas Teknik UNESA, Surabaya. 